\title{
Experimental study on the effect of arches setting on semi-flexible monocrystalline solar panels
}

\author{
Iwan Arissetyadhi ${ }^{1}$, Tresna Dewi $^{\star 2}$, RD Kusumanto ${ }^{3}$ \\ Applied Master of Renewable Energy Engineering, Politeknik Negeri Sriwijaya, Indonesia ${ }^{1}$ \\ Sub-Division Communication, PT. PLN (Persero)UIWS2JB, Indonesia ${ }^{1}$ \\ Electrical Engineering Department, Politeknik Negeri Sriwijaya, Indonesia ${ }^{2,3}$
}

\section{Article Info \\ Keywords: \\ Concave, Convex, Photovoltaic, Renewable \\ Energy, Solar Energy}

Article history:

Received 04 March 2020

Revised 09 April 2020

Accepted 12 May 2020

Available 15 May 2020

Cite:

Arissetyadhi, I., Dewi, T., \& Kusumanto, R. (2020). Experimental Study on The Effect of Arches Setting on Semi-Flexible

Monocrystalline Solar Panels. Kinetik: Game

Technology, Information System, Computer

Network, Computing, Electronics, and Control,

$5(2)$

doi:https://doi.org/10.22219/kinetik.v5i2.1055

${ }^{*}$ Corresponding author

Tresna Dewi

E-mail address:

tresna_dewi@polsri.ac.id

\section{Introduction}

The quest for renewable energy is leaving lots of homework for practitioners, researchers, and government. Even though renewable energy sources such as sunlight and wind energy give a promising future, there are still many more obstacles on the way of harvesting the energies. Indonesia situating in equator has lots of potential for harvesting energy from the sun; however, the ever summer countries have the same problem of high temperature all year long. Unfortunately, the Photovoltaic (PV) system is prone to overheated panels, which lead to the decrement of energy yield [1][2][3][4].

Several methods had been carried out to increase the energy produced by solar panels applied in a tropical country such as Indonesia. This method includes applying the cooling system to overcome overheat or installing a reflecting mirror to increase the amount of solar irradiance captured by the PV panels. Ahmed and Bawa in 2018 investigated the reflective mirror effect on the performance of the hybrid PV/thermal water collector by building two prototypes of the hybrid solar collector to compare the thermal and electrical performance. The reflective mirror increase temperature to $92.7 \mathrm{oC}$ from $52.750 \mathrm{C}$ without the addition of a reflective mirror, and subsequently increase the electrical efficiency [5]. Siahaan and Siswono 2019 investigated the tilt angle of a reflector (flat, concave, and convex mirror) to the increment of the energy yield of solar panels. They found that the $90 \mathrm{o}$ tilt angle gave the maximum output [6]. Patanasemakul et al. in 2017 used reflective secondary optic to improve radiation uniformity in concentrating sun incident and improve the fill factors up to $5-15 \%$, and maximum power up to $10 \%$ improvement [7]. However, the reflective mirror does not apply for PV system applications that required motion, such as PV panels to power a mobile robot applied in agriculture. Even for the common PV solar plant, the application of the reflective mirror can increase the installation cost, for it requires to purchase many mirrors.

In an attempt to improve irradiance absorption on the panel surface, a bifacial PV module is produced and investigated. Bifacial PV modules that can harvest the sun incident both from the front and rear surface of PV panels is considered ideal for producing more electricity compared to conventional. The bifacial panels can be installed at any tilt angle and receive more sunlight than the mono facial PV panels. The irradiance does not only come directly from the sunlight but also reflection from the ground or rooftop. Saw et al. in 2017 applied bifacial PV modules to enhance the optical performance, and the result showed that the white reflective coating generated $3 \%$ more current [8]. LopezGarcia et al., in 2019, investigated the electrical performance of bifacial silicon PV modules under different mounting

Cite: Arissetyadhi, I., Dewi, T., \& Kusumanto, R. (2020). Experimental Study on The Effect of Arches Setting on Semi-Flexible Monocrystalline Solar Panels. Kinetik: Game Technology, Information System, Computer Network, Computing, Electronics, and Control, 5(2). doi:https://doi.org/10.22219/kinetik.v5i2.1055

\begin{abstract} However, the energy potential from the sun is not maximally utilized. One of panels in arches setting. This setting is made possible by the availability of the semi-flexible monocrystalline solar panel. This paper investigates the
increment of harvested power and efficiency by arranging the solar panel in where Palembang experiences the dry season and January 2020 during the $(13.14 \%)$ were achieved in a concave setting during the dry season. The convex setting produced more power and efficiency (13.26 Watt and 9.30\%) compared to the plane setting $(10.24$ Watt and $9.71 \%)$. These results show
that arches setting are more efficient to harvest solar power and give more extensive applications such as to power a dynamics mobile robot applied in agriculture.
\end{abstract}


configurations and found a 20\% increment in Pmax produced [9]. Yusufoglu et al., in 2014, simulated energy production by bifacial modules with revision of ground reflection, and by tilting to optimum angle, the energy produced can be improved up to $30 \%$ theoretically [10]. Wang et al. in 2015 developed a model to calculate power and energy yield and to identify the suitable bifacial PV application and market. Wang et al. came with $10 \%$ of energy yield achieved by $20 \%$ rear reflection [11]. Lamers et al. in 2018 found out that the temperature effects of bifacial modules were getting 15\% additional heat. However, energy production was still higher due to bifacial gain [12]. Rahman and Khan in 2010 enhanced the performance of the standalone PV system by $25 \%$ in short circuit currents by applying a mirror as the reflector [13]. Pham et al. in 2019

compared PV and reflective shade in an urban environment to see the effect on pedestrian thermal comfort. Pham et al. claimed that the sensible heat flux of the PV installed area is $80 \%$ higher than the open asphalt road. Even at night, neat fluxes are still sensible [14][15]. The problem with the bifacial PV module is the price, and the framing design is still in rigid form; therefore, at some point, the application is still limited to the stationary implementation.

The stationary applications of a PV system are including mounting installation such as masjid rooftop Elshurafa et al. in 2019 [16], and how Abreu et al. 2019 studied the adoption of rooftop PV System toward the public acceptance of rooftop PV [17]. Even the stationary application demands the aesthetical concept, which can not be provided by the rigid conventional solar panels [18][19[[20]. By considering the total integration of solar panels to a building, a zero energy building can be realized as presented by Song et al. in 2008 [21] and Kim et al. in 2015[22], and the rigid conventional panels can not installed optimally as a wall. The thin-film solar panel might be the answer to create a PV panel integrated building with thin PV panels, and color customization is possible to meet the aesthetic requirement. However, thin-film panel efficiency is less than crystalline PV panels, and the price is higher than it.

Fortunately, the latest technology of PV panels is a semi-flexible solar panel with thin finishing framing that makes the panel installation is more flexible for more applications, such as a moving application to power robot in agriculture [23][24][25]. This paper discusses the performance comparison of semi-flexible monocrystalline solar panels install in convex, concave, and flat. The performances of the semi-flexible solar panel compared to the conventional flat monocrystalline solar panel. The objectives of this study are to compare the semi-flexible performance, and the possibility to apply the panel to robotics application installed in convex, concave, and flat. The data were taken for two days in the dry season and two days in the rainy season. The experiment was conducted in Palembang, South Sumatra, Indonesia, which has two seasons in a year, the dry season peak in August, and the rainy season peak in January.

\section{Research Method}

This paper investigates the advantage of implementing semi-flexible solar panels compare to the conventional rigid panel in terms of the power produced and the efficiency. This study is also to show the possibility of installing PV panels to the moving application, such as to power robotics application in agriculture.

\subsection{Electricity Generation by PV effect}

PV effect enables the direct conversion from sunlight into electricity using a semiconductor material called a solar cell. The incident from the sun excites the electrons to move to a higher state and living a hole behind, the combination of electrons and holes motion generate current and voltage. The generated electricity highly dependent on some factors that are affecting the amount of sunlight that hits the panels. These factors are including shading and panel surface temperature that is a very decisive factor for electricity yield. Figure 1 shows the illustration of electricity generation using the PV effect. Figure 2 shows the implementation of the panel setting considered in this study to compare the effectiveness of the proposed method.

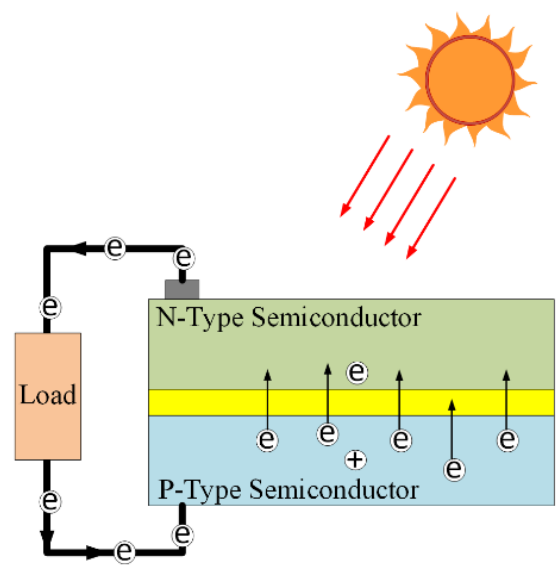

Figure 1. Electricity Generation using PV Effect

(C) 2020 The Authors. Published by Universitas Muhammadiyah Malang

This is an open access article under the CC BY SA license. (https://creativecommons.org/licenses/by-sa/4.0/) 
The common application of conventional solar panel is by tilting the panel according to the location longitude and altitude, such as Palembang is situated in $2.9761^{\circ} \mathrm{S}, 104.7754^{\circ} \mathrm{E}$; therefore, the panel should be tilted to $3^{\circ}$ facing the sun. However, $3^{\circ}$ inclination lacks cleaning power during the rain. The $3^{\circ}$ can be increased to $10^{\circ}$. The conventional setting is given in Figure 2a. The quest to achieve the maximum incidents is including setting the panel imitating convex mirror where all the incidents if trapped by reflecting the incident back to the surface of the panel. This setting is made possible by the implementation of the semi-flexible solar panel. This setting is illustrated by Figure $2 \mathrm{~b}$. During the motion application that requires the panels to move from one point to another, there might be a situation where the panel is not receiving any incidents. The situation can be overcome by bending the panel, and ensuring the panel gets all the sun rays from any direction. This panel set is illustrated in Figure 2c, where $\theta_{p n}, \theta_{C v}$, and $\theta_{C x}$ are the tilt angle for a plane, concave, and convex setting, respectively.

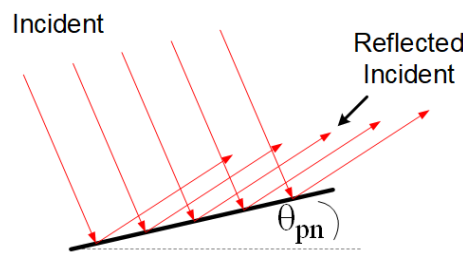

(a). Plane setting

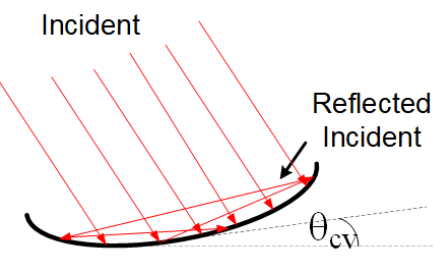

(b). Concave setting

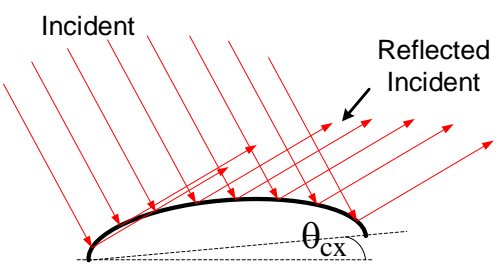

(c). Convex setting

Figure 2. Incidents Received by a Solar Panel with Different Surface Setting

The performance of solar panels setting in Figure 2 are compared in term of maximum power generated, and efficiency of the generated power, where the solar panel fill factor and efficiency is given in Equation 1 and Equation 2.

$$
\begin{gathered}
F F=\frac{P_{M P}}{v_{o c} \times i_{s c}} \\
\eta=\frac{P_{\max }}{P_{\text {in }}} \times 100 \%=\frac{v_{o c} i_{s c} F F}{P_{\text {in }}}
\end{gathered}
$$

where FF is the fill factor, $P_{M P}$ is the power maximum point, $v_{o c}$ is the open-circuit voltage, $i_{s c}$ is the short circuit current, $\eta$ is the efficiency, $P_{\max }$ is the maximum power achieved, and $P_{i n}$ is the input power.

\subsection{Optics of flat and concave interface}

The optics of PV panels settings in this study is given in Figure 3, the incident reflection in a plane is in Figure $3 a$ and curve surface in Figure $3 \mathrm{~b}$, where the concave and convex surface are considered curve surface.

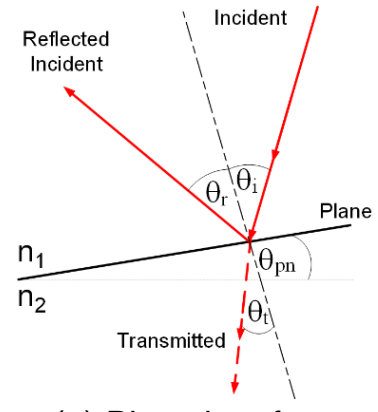

(a) Plane interface

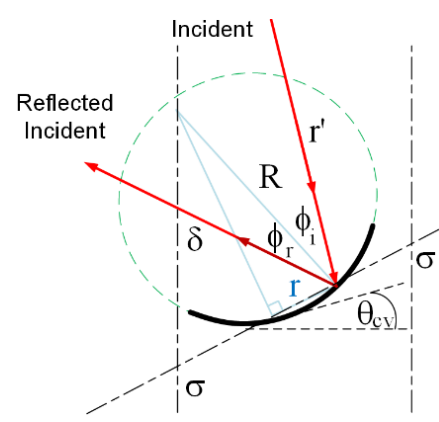

(b) Curve surface

Figure 3. Incident Reflection Properties in the Plane and Curve Surface

The incident reflection in a plane interface in Figure 3 a takes the properties of electromagnetic waves transversing an interface between $\mathrm{n}_{1}$ (real medium) and $\mathrm{n}_{2}$ (absorbing medium) [26]. The angle between the incident and normal $\left(\theta_{i}\right)$ and reflected incident $\left(\theta_{r}\right)$ are the same or $\theta_{i}=\theta_{r}$. While the relation between the coming incident and the transmitted one is given by Equation 3 .

$$
n_{1} \sin \theta_{i}=n_{2} \sin \theta_{t}
$$

where $\theta_{t}$ is the angle between the transmitted incident and normal.

Cite: Arissetyadhi, I., Dewi, T., \& Kusumanto, R. (2020). Experimental Study on The Effect of Arches Setting on Semi-Flexible Monocrystalline Solar Panels. Kinetik: Game Technology, Information System, Computer Network, Computing, Electronics, and Control, 5(2). doi:https://doi.org/10.22219/kinetik.v5i2.1055 
The reflection properties of curve mirror and the relationships among angles formed $(\delta, \sigma)$ due to the coming incident Figure $3 \mathrm{~b}$ are Equation 4.

$$
\phi_{i}=\sigma+r^{\prime}-\frac{\pi}{2}, \delta=\phi_{i}+\sigma-\frac{\pi}{2}, \text { and } r_{o u t}^{\prime}=r_{i n}^{\prime}+\frac{2 r}{R}
$$

where the angle between the incident and normal $\left(\phi_{i}\right)$ and reflected incident $\left(\phi_{r}\right)$ on the concave mirror are the same or $\phi_{i}=\phi_{r}, R$ and $r$ are the illustrations of triangle properties formed to show the relationships among angles where $r$ is the height of triangle and $R$ is the hypotenuse, $r^{\prime}$ is the slope of the incoming incident and $\delta+\sigma=180^{\circ}$.

\section{Results and Discussion}

The objective of this research is to investigate the effect of arches setting on a semi-flexible monocrystalline solar panel. This study compares energy yield and efficiency produced by a conventional solar panel and curved semi-flexible panels. The hypothesis shows that the concave setting might produce the highest power due to the nature of this setting to trap incident to ensure more extended electrons' lifetime and prevent electron-hole recombination. The experiment is conducted in Palembang Indonesia with a coordinate location of $2^{\circ} 55^{\prime} 17.9^{\prime \prime} S 104^{\circ} 41^{\prime} 56.7^{\prime \prime E}-2.921650,104.699076$. The data was collected in two steps during the dry season in the $12^{\text {th }}-13^{\text {rd }}$ of August 2019 and the rainy season from $15^{\text {th }}-16^{\text {th }}$ of January 2020. This timing is chosen to show energy yield during two types of weather seasons in tropical Palembang city. The experiment set is shown in Figure 4, where Figure 4a shows the dimension and setting of the panels, and Figure $4 \mathrm{~b}$ shows the installation of the actual panels.

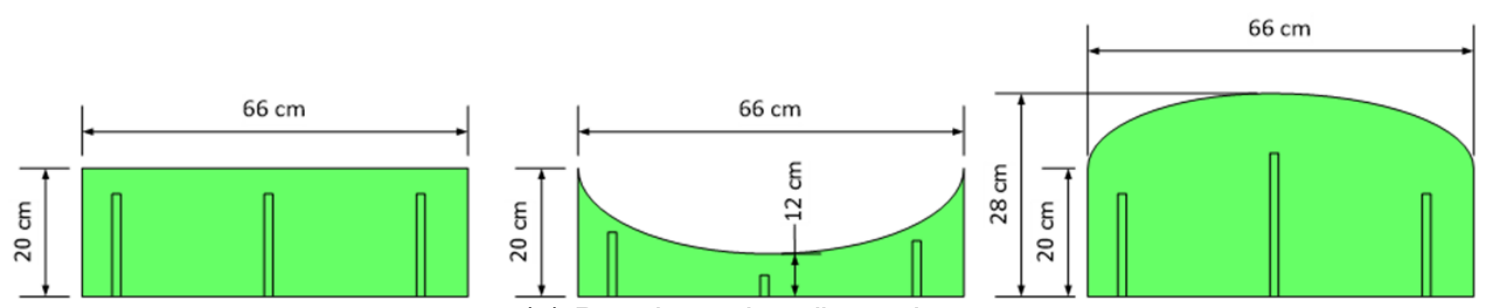

(a) Panels setting dimension

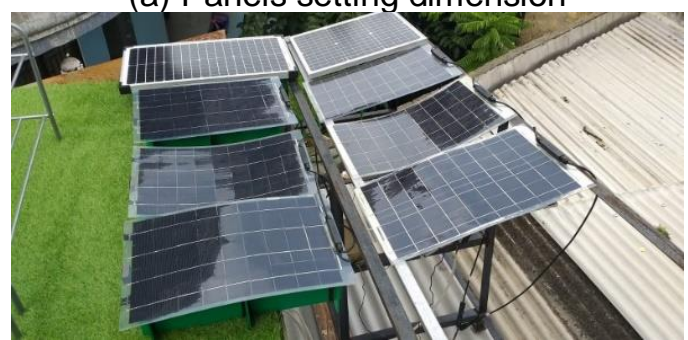

(b) Panels installation

Figure 4. Experimental Setting

\subsection{Experimental data were taken during dry-season August $12^{\text {th }}-13^{\text {th }}, 2019$}

The first data collection was conducted on August $12^{\text {th }}-13^{\text {th }}, 2019$, in which the peak of the dry season in Palembang, Indonesia. Data from Meteorological, Climatological, and Geophysical Agency (BMKG) in Palembang shows that the maximum temperature on August $12^{\text {th }}, 2019$ was $33.9^{\circ} \mathrm{C}$, the highest humidity was $77 \%$, the peak sun hours was 5 hours, and the average wind speed was $3 \mathrm{~m} / \mathrm{s}$. The maximum temperature on August $13^{\text {th }}, 2019$ was $24^{\circ} \mathrm{C}$, the average temperature was $77 \%$, the peak sun hours was 7 hours, and the average wind speed was $4 \mathrm{~m} / \mathrm{s}$.

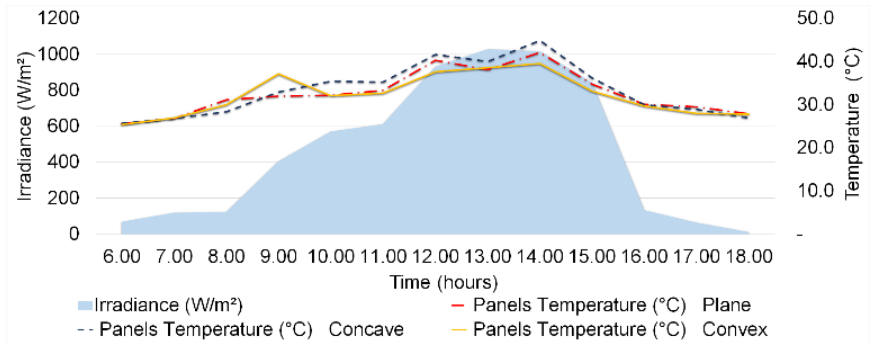

(a) Irradiance and temperature on August $12^{\text {th }}, 2019$

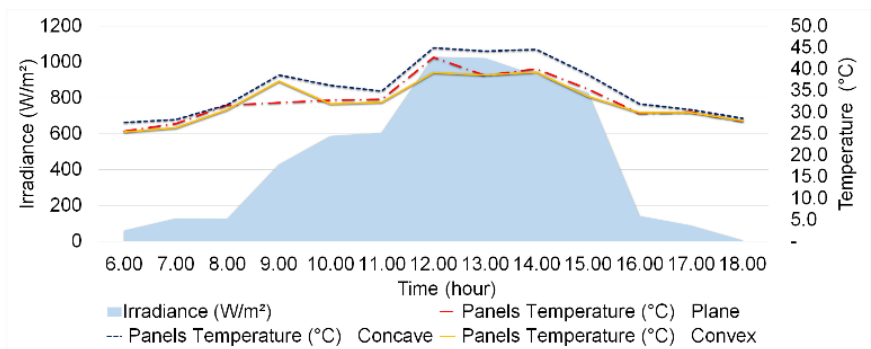

(b) Irradiance and temperature on August $13^{\text {th }}, 2019$

Figure 5. Irradiance and Temperature on August $12^{\text {th }}-13^{\text {th }}, 2019$ 
Figure 5 shows the irradiance and solar panels' temperature on August $12^{\text {th }}-13^{\text {th }}, 2019$. The highest temperature is measured in the concave setting due to the solar irradiance trapped and reflected inside the curve. Figure 6 shows the Voc and Isc measured on August $12^{\text {th }}-13^{\text {th }}, 2019$. Voc is the maximum voltage available from the panels, and isc is the current generated during the collection of light-generated carriers and occurs when the voltage is zero. Voc and Isc are required to calculate the fill factor. Figure 6 shows that Voc and Isc measured from the concave solar panel are higher than the plane and convex setting.

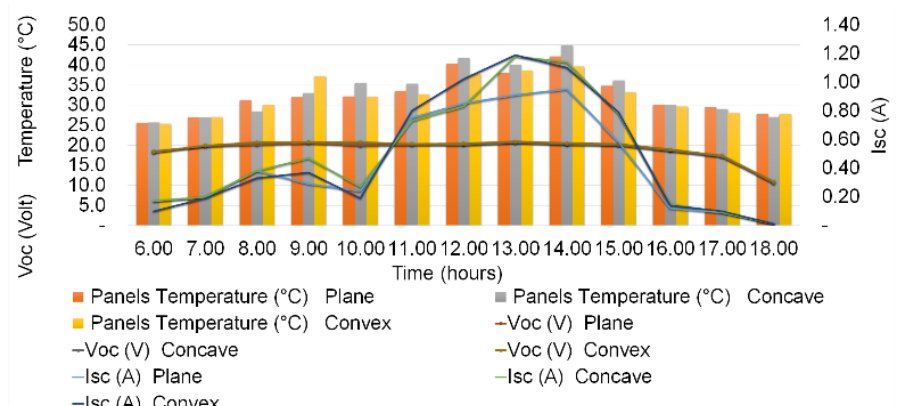

(a) Voc and Isc measured on August $12^{\text {th }}, 2019$

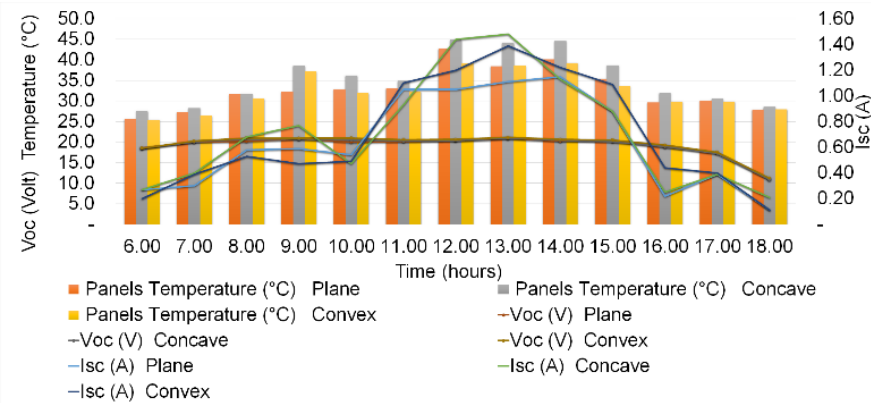

(b) Voc and Isc measured on August $13^{\text {th }}, 2019$

Figure 6. Voc and Isc Measured on August $12^{\text {th }}-13^{\text {th }}, 2019$

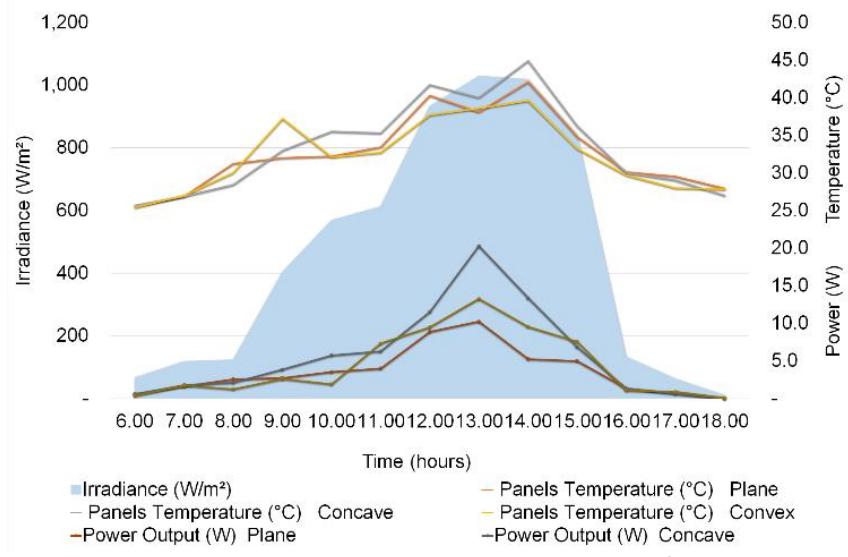

(a) The power produced on August $12^{\text {th }}, 2019$

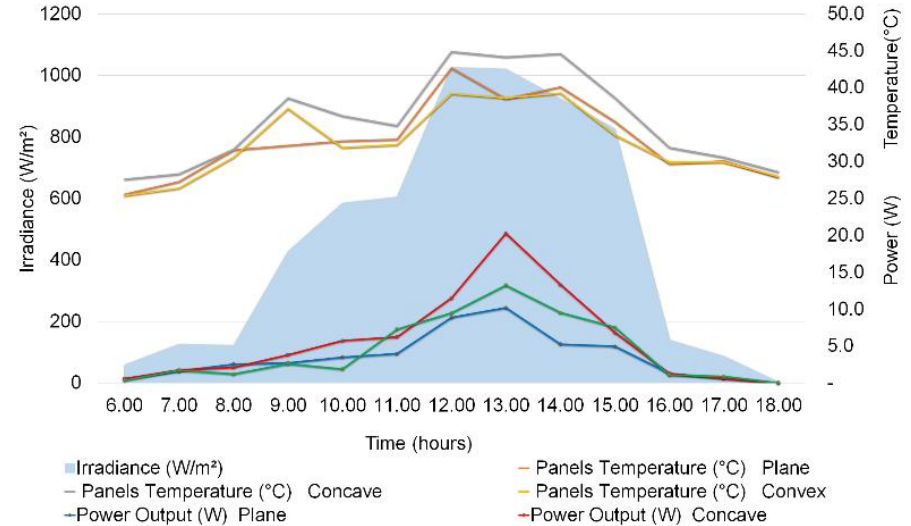

(b) The power produced on August $13^{\text {th }}, 2019$ Figure 7. Power Produced on August $12^{\text {th }}-13^{\text {th }}, 2019$

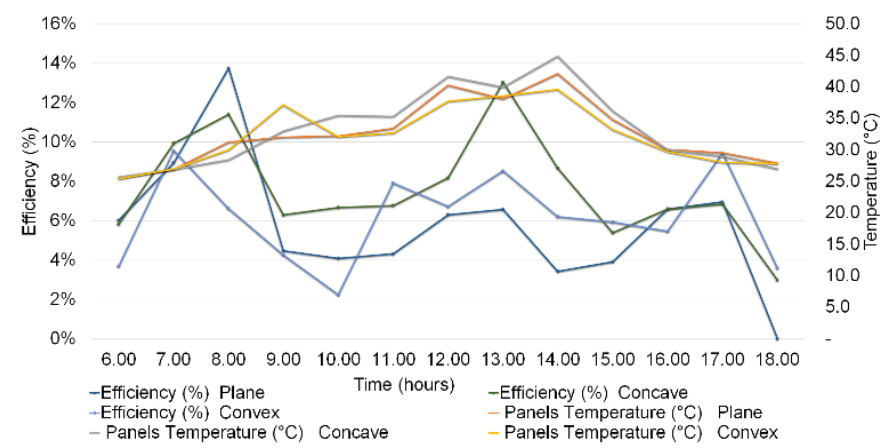

(a) Efficiency produced on August $12^{\text {th }}, 2019$

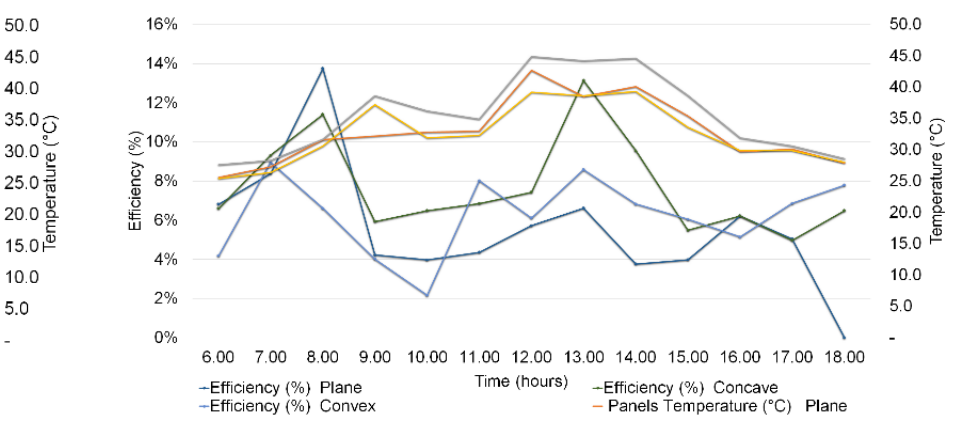

(b) Efficiency produced on August $13^{\text {th }}, 2019$ Figure 8. Efficiency Produced on August $12^{\text {th }}-13^{\text {th }}, 2019$

The higher the intensity of solar radiation received by the solar panel, the panels surface temperature also increases. Unfortunately, when the solar panel temperature increases more than the allowed temperature, the produced power could decrease. The increment of solar radiation intensity determines the output power of the solar panel. This condition makes the power output to be fluctuating prone to shading and weather change, for example, from sunny to cloudy. Figure 7 shows the produced power on August $12^{\text {th }}-13^{\text {th }}, 2019$. The highest output power is produced by the 

concave surface, 20.27 Watt. The difference between concave and plane setting averagely is 10.05 Watt, and the difference between concave and convex is 7.013 Watt.

The peak of sun hours in Palembang based on the amount of irradiance received by the panels is 6 hours (10 AM to 03 PM). By considering the peak sun hours as shown in Figure 8, the highest efficiency is achieved by concave setting on $13^{\text {th }}$ of August 2019 that is $13.14 \%$ compared to the highest efficiency of the plane $\left(6.62 \%\right.$ on $13^{\text {th }}$ of august, 2019) and convex setting (8.59\% on $13^{\text {th }}$ of August 2019).

\subsection{Experimental data were taken during rainy-season August $12^{\text {th }}-13^{\text {th }}, 2019$}

The next data collection was conducted on the $15^{\text {th }}-16^{\text {th }}$ of January 2020 . January is the peak of the rainy season in Indonesia. Data from Meteorological, Climatological, and Geophysical Agency (BMKG) in Palembang shows that the maximum temperature was $32.5^{\circ} \mathrm{C}$, the highest humidity was $86 \%$, the peak sun hours was 7.4 hours, and the average wind speed was $2 \mathrm{~m} / \mathrm{s}$.

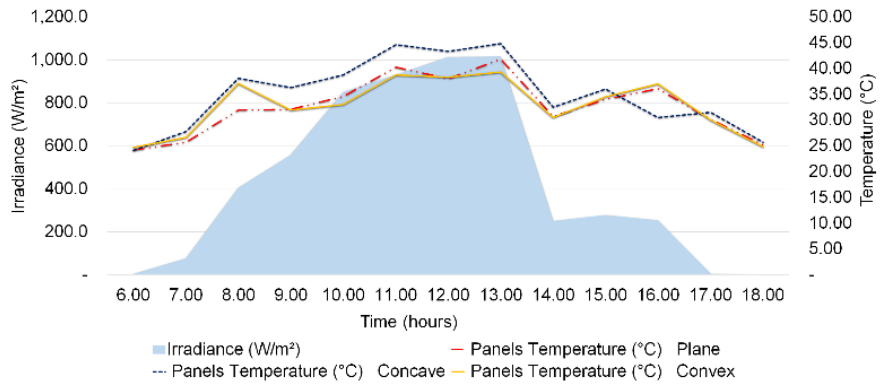

(a) Irradiance and temperature on January $15^{\text {th }}, 2020$

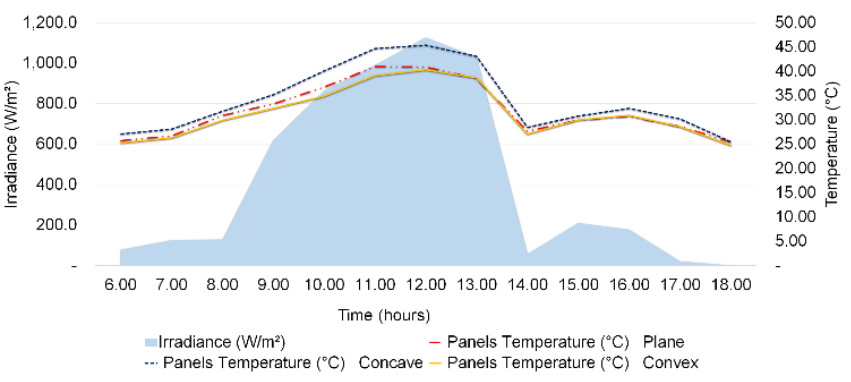

(b) Irradiance and temperature on January $16^{\text {th }}, 2020$

Figure 9. Irradiance and Temperature on January $15^{\text {th }}-16^{\text {th }}, 2020$

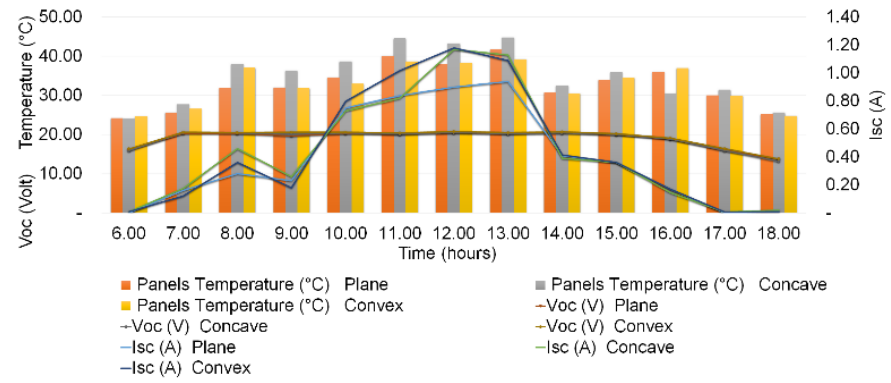

(a) Voc and Isc measured on January $15^{\text {th }}, 2020$

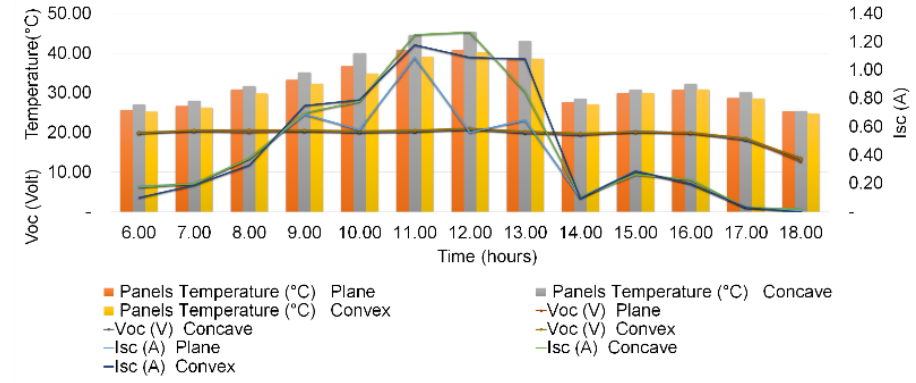

(b) Voc and Isc measured on January $16^{\text {th }}, 2020$

Figure 10. Voc and Isc Measured on January $15^{\text {th }}-16^{\text {th }}, 2020$

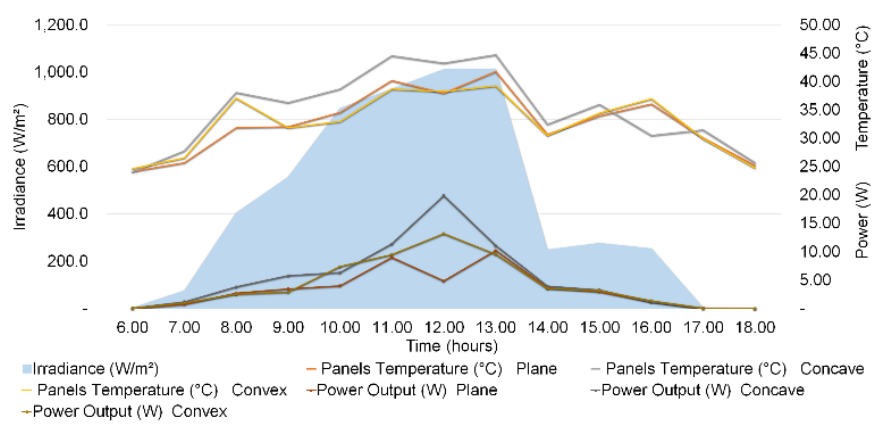

(a) The power produced on January $15^{\text {th }}, 2020$

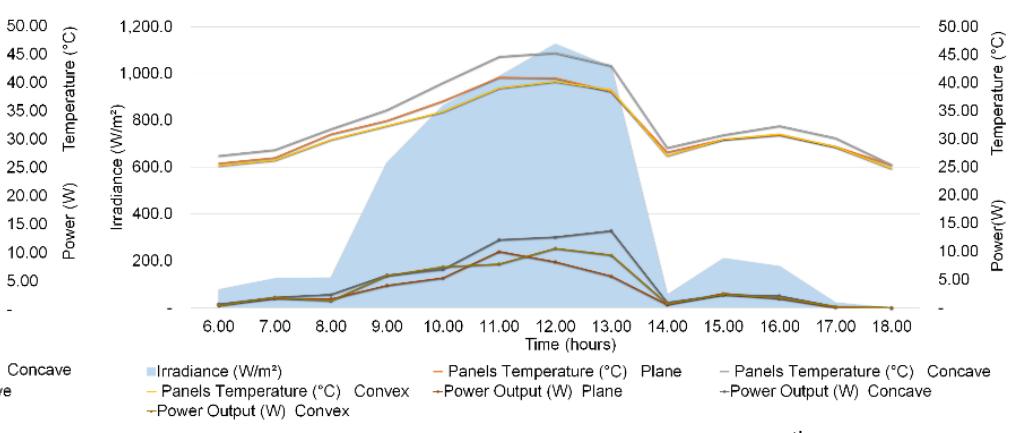

(b) The power produced on January $16^{\text {th }}, 2020$

Figure 11. Power Produced on January $15^{\text {th }}-16^{\text {th }}, 2020$

The relation between the increment of irradiance and temperature in the rainy season is shown in Figure 9, whereas the irradiance increase, the panel surface temperature also increases. The irradiance increment affects the Voc (Figure 10), Isc (Figure 10), and the power generated (11). The highest generated output is shown in the concave setting, as predicted by the hypothesis. The efficiency of concave setting panels is also higher than the plane and convex setting. 


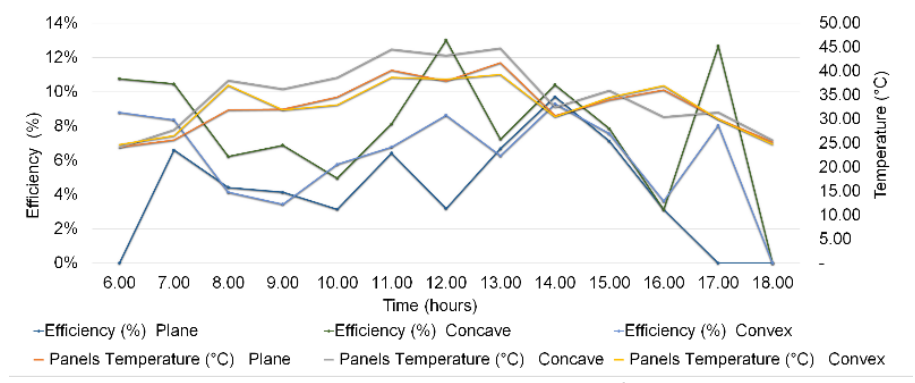

(a) Efficiency on January $15^{\text {th }}, 2020$

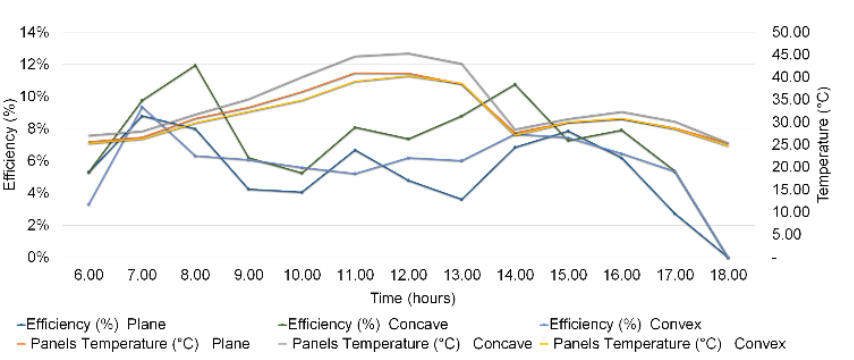

(b) Efficiency on January $16^{\text {th }}, 2020$

Figure 12. Efficiency on January $15^{\text {th }}-16^{\text {th }}, 2020$

The data taken during the rainy season (January $15^{\text {th }}-16^{\text {th }}, 2020$ ) is similar to the data retrieved during the dry season (August $12^{\text {th }}-13^{\text {th }}, 2019$ ). Figure 11 shows the produced power on January $15^{\text {th }}-16^{\text {th }}, 2020$. The highest output power is produced by concave surface, that is 19.93 Watt. The difference between concave and the plane set is 9.69 Watt, and the difference between concave and convex is 6.72 Watt on January $16^{\text {th }}, 2020$. The produced power on January $16^{\text {th }}, 2020$, was less due to weather factors. The highest output power is produced by a concave surface ( 13.70 Watt). The difference between concave and plane setting averagely is 3.71 Watt, and the difference between concave and convex is 3.14 Watt

The peak of sun hours in Palembang based on the amount of irradiance received by the panels is 6 hours ( 10 AM to 03 PM). By considering the peak sun hours as shown in Figure 12, the highest efficiency is achieved by concave setting on $15^{\text {th }}$ of August 2019 that is $13.02 \%$ compared to the highest efficiency of the plane $\left(9.71 \%\right.$ on $15^{\text {th }}$ of January $2020)$ and convex setting $\left(9.30 \%\right.$ on $15^{\text {th }}$ of January 2020$)$.

The experimental data taken on the dry and rainy season are similar where the highest power and efficiency achieved by the concave setting. The second highest setting is the convex setting. These results prove that the arches setting increases the generated power and efficiency of monocrystalline solar panels. These settings give more extensive applications, especially for dynamics applications such as panels to power a robot.

\section{Conclusion}

The arches' setting of the semi-flexible monocrystalline solar panel increases the generated electricity and efficiency. This paper discusses the application of arches setting to prepare the panels for a wide range of applications. The data were taken in August 2019, where Palembang experience the dry season and January 2020 during the rainy season. The highest power produced (20.27 Watt) and efficiency $(13.14 \%)$ are on the concave setting during the dry season. The convex setting produced more power and efficiency (13.26 Watt and $9.30 \%)$ compared to the plane setting $(10.24$ Watt and $9.71 \%)$. These results show that arches setting are more efficient to harvest solar power and give more comprehensive application such as to power a dynamics mobile robot applied in agriculture.

\section{References}

[1] T. Dewi, P. Risma, Y. Oktarina, M.T. Roseno, H.M. Yudha, A. S. Handayani, and Y. Wijanarko, "A Survey on Solar Cell; The Role of Solar Cell in Robotics and Robotic Application in Solar Cell industry," in Proceeding Forum in Research, Science, and Technology (FIRST), 2016.

[2] T. Dewi, P. Risma, and Y. Oktarina, Y. "A Review of Factors Affecting the Efficiency and Output of a PV system Applied in Tropical Climate," in IOP Conference Series: Earth and Environmental Science 258012039 ICoSITer 2018, 2019. https://doi.org/10.1088/17551315/258/1/012039.

[3] H.A. Harahap, T. Dewi, and Rusdianasari, "Automatic Cooling System for Efficiency and Output Enhancement of a PV System Application in Palembang, Indonesia," in 2nd Forum in Research, Science, and Technology, IOP Conf. Series: Journal of Physics: Conf. Series 1167 012027, 2019. https://doi.org/10.1088/1742-6596/1167/1/012027.

[4] H. M. Yudha, T. Dewi, P. Risma, and Y. Oktarina, "Life Cycle Analysis for the Feasibility of Photovoltaic System Application in Indonesia," in IOP Conference Series: Earth and Environmental Science 124 012005, 2018. https://doi.org/10.1088/1755-1315/124/1/012005.

[5] O.K. Ahmed and S. M. Bawa, "Reflective Mirrors Effect on the Performance of the Hybrid PV/Thermal Water Collector," Energy for Sustainable Development, Vol. 43, Pp. 235-246, 2018. https://doi.org/10.1016/j.esd.2018.02.001.

[6] Y. Siahaan and H. Siswono, "Analysis the Effect of Reflector (Flat Mirror, Convex Mirror, and Concave Mirror) on Solar Panel," International Journal of Power Electronics and Drive System (IJPEDS), Vol. 10, No. 2, Pp. 943-952, 2019. ISSN: 2088-8694, https://doi.org/10.11591/ijpeds.v10.i2.pp943-952.

[7] N. Patanasemakul, P. Rakkwamsuk, S. Chuangchote, R. Songprakorp, and K. Kirtikara, "Improved Radiation Uniformity in Concentrating Photovoltaic System using Reflective Secondary Optic," in 2017 International Conference on Alternative Energy in Developing Countries and Emerging Economies, Energy Procedia, Vol. 138, Pp. 598-603, 2017. https://doi.org/10.1016/j.egypro.2017.10.167.

[8] M. H. Saw, Y. S. Khoo, J. P. Singh, and Y. Wang, "Enhancing Optical Performance of Bifacial PV Modules," in 7th International Conference on Silicon Photovoltaics, SiliconPV 2017, 3-5 April 2017, Freiburg, Germany, Energy Procedia, Vol 124, Pp. 484-494, 2017. https://doi.org/10.1016/j.egypro.2017.09.285

[9] J. Lopez-Garcia, A. Casaddo, and T. Sample, "Electrical Performance of Bifacial Silicon PV Modules under different Indoor Mounting Configuration Affecting the Rear Reflected Irradiance," Solar Energy, Vol 177, Pp. 471-482, 2019. https://doi.org/10.1016/j.solener.2018.11.051. 
[10] U. A. Yusufoglu, T. H. Lee, T. M. Pletzer, A. Halmb, L. J. Koduvelikulathu, C. Comparotto, R. Kopecek, H. Kurza, "Simulation of Energy Production by Bifacial Modules with Revision of Ground Reflection," in Proceedings of the 4th International Conference on Crystalline Silicon Photovoltaics (SiliconPV 2014), Energy Procedia, Vol. 55, Pp. 389-395, 2014. https://doi.org/10.1016/.jegypro.2014.08.111.

[11] S. Wang, O. Wilkie, J. Lam, R. Steem, W. Zhang, K. S. Khoo, S. C. Siong, H. Rostan, "Bifacial Photovoltaic Systems Energy Yield Modelling," in 5th International Conference on Silicon Photovoltaics, SiliconPV 2015, Energy Procedia, Vol. 77, Pp. 428-433, 2015. https://doi.org/10.1016/j.egypro.2015.07.060.

[12] M.W.P.E. Lamers, E. Özkalay, R.S.R. Gali, G.J.M. Janssen, A.W.Weeber, I.G.Romijn, and B.B.Van Aken, "Temperature effects of bifacial modules: Hotter or cooler?," Solar Energy Materials and Solar Cells, Vol. 185, Pp. 192-197, 2018. https://doi.org/10.1016/j.solmat.2018.05.033

[13] R. Rahman and M. F. Khan, "Performance enhancement of PV Solar System by mirror reflection," in International Conference on Electrical \& Computer Engineering (ICECE 2010), Dhaka, Pp. 163-166, 2010. https://doi.org/10.1109/ICELCE.2010.5700652.

[14] J. V. Pham, A. Baniassadi, K. E.Brown, J. Heusinger, and D. J.Sailor, "Comparing Photovoltaic and Reflective Shade Surfaces in the Urban Environment: Effects on Surface Sensible Heat Flux and Pedestrian Thermal Comfort," Urban Climate, Vol. 29, 100500, 2019. https://doi.org/10.1016/j.uclim.2019.100500.

[15] E. Biyik, M. Araz, A. Hepbasli, M. Shahrestan, R. Yao, E. Essah, A. C. Oliveira, T. del Cano, J. L. Lechon, L. Andrade, A. Mendes, Y. B. Atlí, "A key review of building integrated photovoltaic (BIPV) systems," Engineering Science and Technology, an International Journal, Vol. 20, No. 3, Pp. 833-858, 2017. https://doi.org/10.1016/j.jestch.2017.01.009.

[16] A. M. Elshurafa, A. M. Alsubaie, A. A. Alabduljabbar, and S. A. Al-Husaien, "Solar PV on Mosque Rooftops: Results from a Pilot Study in Saudi Arabia," Journal of Building Engineering, Vol. 25, 100809, 2019. https://doi.org/10.1016/j.jobe.2019.100809.

[17] J. Abreu, N. Wingartz, and N. Hardy, "New trends in solar: A Comparative Study Assessing the Attitudes Towards the Adoption of Rooftop PV," Energy Policy, Vol. 128, Pp. 347-363, 2019. https://doi.org/10.1016/j.enpol.2018.12.038.

[18] P. Huang, M. Lovati, X. Zhang, C. Bales, S. Hallbeck, A. Becker, H. Bergqvist, J. Hedberg, L. Maturi, "Transforming a Residential Building Cluster into Electricity Prosumers in Sweden: Optimal Design of a Coupled PV-heat pump-thermal Storage-electric Vehicle system," Applied Energy, Vol. 255, 113864, 2019. https://doi.org/10.1016/j.apenergy.2019.113864.

[19] M. Wang, J. Peng, H. Yang, and Y. Luo, "Performance Evaluation of Semi-transparent CdTe Thin Film PV Window Applying on Commercial Buildings in Hong Kong," Energy Procedia, Vol. 152, Pp. 1091-1096, 2018. https://doi.org/10.1016/j.egypro.2018.09.131.

[20] L. Aelenei, R. Pereira, A. Ferreira, H. Gončalves, and A. Joyce, "Building Integrated Photovoltaic System with Integral Thermal Storage: A Case Study," Energy Procedia, Vol. 58, Pp. 172-178, 2014. https://doi.org/10.1016/j.egypro.2014.10.425.

[21] J.H. Song, Y. S. .Ana, S. G. Kim, S. J. Lee, J. H. Yoo, and Y. K. Choung, "Power Output Analysis of Transparent Thin-Film Module in Building Integrated Photovoltaic System (BIPV)," Energy and Buildings, Vol. 40, No. 11, Pp. 2067-2075, 2008. https://doi.org/10.1016/j.enbuild.2008.05.013.

[22] J. H. Kim, H. R. Kim, and J.T. Kim, "Analysis of Photovoltaic Applications in Zero Energy Building Cases of IEA SHC/EBC Task 40/Annex 52," Sustainability, Vol. 7, Pp. 8782-8800, 2015. https://doi.org/10.3390/su7078782.

[23] J. Iqbal and Z. H. Khan, "The Potential Role of Renewable Energy Sources in Robot's Power System: A Case Study of Pakistan," Renewable and Sustainable Energy Reviews, Vo 75, Pp. 106-122, 2017. https://doi.org/10.1016/j.rser.2016.10.055.

[24] A. Ghobadpoura, L. Boulon, H. Mousazadeh, A. S. Malvajerdi, S. Rafiee, "State of the Art of Autonomous Agricultural Off-road Vehicles Driven by Renewable Energy Systems," Energy Procedia, Vol. 162, Pp. 4-13, 2019. https://doi.org/10.1016/j.egypro.2019.04.002.

[25] N.M Kumar, K. Sudhakar, M. Samykano, and S. Sukumaran, "Dust Cleaning Robot (DCR) for BIPV and BAPV Solar Power Plant-A Conceptual Framework and Research Challenge," in International Conference on Robotics and Smart Manufacturing (RoSMa2018), Procedia Computer Science, Vol 133, Pp. 746-754, 2018, https://doi.org/10.1016/j.procs.2018.07.123.

[26] K. Jäger, O., Isabella, A. H. M. Smets, R. A. C. M. M. van Swaaij, and M. Zeman, "Solar Energy: Fundamentals, Technology, and Systems," Delft University of Technology, UIT CAMBRIDGE LTD, ISBN/EAN: 1906860327 / $9781906860325,2014$. 